\title{
Strains of Pseudomonas putrefaciens from clinical material
}

\author{
B. HOLMES, S. P. LAPAGE, AND H. MALNICK \\ From the Computer Trials Laboratory and National Collection of Type Cultures, Central Public Health \\ Laboratory, Colindale, London
}

SYNOPSIS Eight strains of Pseudomonas putrefaciens have been received from among 466 strains of Pseudomonas submitted to the Computer Trials Laboratory for identification over the last eight years. Two of the strains of $P$. putrefaciens from patients with otitis media and otitis externa respectively appear to have played a pathogenic role. The biochemical characteristics of these eight strains were compared with those of seven culture collection strains.

Pseudomonas putrefaciens was first described under the name Achromobacter putrefaciens by Derby and Hammer (1931) who isolated the organism from tainted butter. Long and Hammer (1941) examined strains of this taxon which they isolated from dairy produce, streams, lakes, and moist soil and transferred the species to the genus Pseudomonas. $P$. putrefaciens is a well known fish-spoilage organism having been isolated from fresh, frozen, and stored cod fillets (Castell, Richards, and Wilmot, 1949) and from haddock (Levin, 1968; Chai, Chen, Rosen, and Levin, 1968). Two strains of $P$. putrefaciens from oil brines were described by Iizuka and Komagata (1964), and, according to Hugh (1970), these strains were two of the four strains of $P$. putrefaciens examined by Iizuka and Komagata (1963a and b) and by Komagata, Iizuka, and Takahashi (1965).

Reports of the isolation of strains of Pseudomonas putrefaciens from clinical material have come mainly from the United States of America. King (1964) placed 22 strains of $P$. putrefaciens she examined in one of her unnamed groups designated Ib; two of these strains were isolated from the ear. Thirteen strains of group $\mathrm{Ib}$ were isolated and described by von Graevenitz and Simon (1970); five were from ear discharges of patients with chronic otitis media of which two were isolated several times; four were from chronically infected leg ulcers; three from sputa of patients with pneumonia; and one strain from urine. Gilardi (1972) reported seven strains of $P$. putrefaciens isolated between September 1965 and June 1971; these included three from wounds, one from urine, and two isolated from

Received for publication 24 October 1974. the ear, of which one was isolated in pure culture and judged to be responsible for otitis media. Riley, Tatum, and Weaver (1972) examined 109 cultures of $P$. putrefaciens from clinical specimens, the sources varying from the mouth and throat to various body wounds; these authors did not state, however, if any of their strains were isolated from the ear. Minagawa (1963) isolated strains belonging to this taxon from the stools of patients with acute enteritis suffering from severe abdominal pain and diarrhoea.

The present account reports two cases, one of otitis media and one of otitis externa, caused by Pseudomonas putrefaciens, six additional field isolates of this taxon from clinical material, and the biochemical results obtained from an examination of all these strains and the seven reference strains maintained in the National Collection of Type Cultures, Colindale.

\section{Materials and Methods}

\section{ORGANISMS}

Fifteen strains of Pseudomonas putrefaciens were examined (table I) and comprised eight field strains sent to the Computer Trials Laboratory for identification and seven NCTC strains of which one (NCTC 10695) is a strain of Pseudomonas rubescens. Citing a personal communication with Komagata, Hugh (1970) stated that NCTC 10695 (ATCC 12099) was one of the four strains of $\boldsymbol{P}$. putrefaciens described by lizuka and Komagata (1963b) and also that the latter authors recognized $P$. putrefaciens as an older name for $P$. rubescens (Pivnick, 1954, 1955). On our results NCTC 10695 could not be 


\begin{tabular}{|c|c|c|c|}
\hline Strain No. & Original Strain Designation & Received from & Source \\
\hline \multicolumn{4}{|l|}{ Field Strains } \\
\hline 1 & E631 & C. E. D. Taylor, London & Sputum \\
\hline 2 & E988 & M. Magus, Toronto & Nasal swab \\
\hline 3 & T111/69 & G. I. Barrow, Truro & Oyster \\
\hline 4 & CL 27/72 & J. D. Abbott, Manchester & Ear swab, otitis media \\
\hline 5 & CL 432/72 & I. Ivanov, Dar es Salaam & Pleural fluid \\
\hline 6 & CL 256/73 & I. Ivanov, Dar es Salaam & Cerebrospinal fluid \\
\hline 7 & CL 549/73 & G. A. Fenwick, Newcastle upon Tyne & Tap swab \\
\hline 8 & CL 595/73 & T. L. C. Dale, London & Ear swab, otitis externa \\
\hline \multicolumn{4}{|c|}{ Culture Collection Strains } \\
\hline NCTC 10695 & ATCC 212099, Pseudomonas rubescens & $\begin{array}{l}\text { National Collection of Industrial Bacteria, } \\
\text { NCIB } 8768\end{array}$ & Cutting oil \\
\hline NCTC 10735 & 63 & K. Komagata, Tokyo & Oil brine \\
\hline NCTC 10736 & P-19X & K. Komagata, Tokyo & Haddock \\
\hline NCTC 10737 & I-5 & K. Komagata, Tokyo & Cuttlefish \\
\hline NCTC 10738 & $136-2$ & K. Komagata, Tokyo & Faeces \\
\hline NCTC 10762 & 734 & A. von Graevenitz, New Haven & Pus \\
\hline NCTC 10763 & B89 & A. von Graevenitz, New Haven ${ }^{3}$ & Bottled blood \\
\hline
\end{tabular}

Table I Strains of Pseudomonas putrefaciens examined

${ }^{1}$ NCTC $=$ National Collection of Type Cultures

${ }^{2}$ ATCC = American Type Culture Collection

sStrain received by A. von Graevenitz from R. E. Weaver, Atlanta

distinguished from the isolates of $P$.putrefaciens and hence we would similarly consider $P$. rubescens a junior synonym of $\boldsymbol{P}$. putrefaciens.

CLINICAL DETAILS OF THE FIELD STRAINS Strain 1 was isolated from a 60-year-old woman with a febrile chest infection and bronchospasm. A radiograph of the chest revealed a small opacity in the right mid-zone. The patient responded to tetracycline and antispasmodics. Twelve years previously she was suspected of having tuberculosis and chest radiographs at that time revealed calcified nodules in the left upper zone. The organism is not thought to have played a pathogenic role and was not isolated in pure culture.

Strain 2 was isolated from the nose. Further details are not available.

Strain 3 was isolated from an oyster during an investigation of these shellfish by Barrow and Miller (1969).

Strain 4 was isolated in 1972 from acute otitis media of the right ear of an adult male engineer who in 1966 had undergone submucous resection and bilateral antrostomy. The patient was immediately treated with tetracycline by his own doctor and an ear swab taken during treatment yielded a predominant growth of the organism in question. Sensitivity to tetracycline was not routinely determined for pseudomonads at the laboratory to which the swab was sent. The strain was found sensitive to colistin sulphate by the laboratory and the patient was treated with this antibiotic on their advice. In February 1972 he was referred to the ear, nose and throat specialist who stated that the patient had a 'cart-wheel' drum and a resolving suppurative otitis media. The condition has now resolved.

Strain 5 was isolated from pleural fluid in mixed culture with Proteus and considered to be a cone taminant.

Strain 6 was isolated in mixed culture wit Klebsiella from the cerebrospinal fluid of a 1-year-old girl with suspected meningitis and also thought to be only a contaminant.

Strain 7 was isolated from a tap swab taken in a hospital intensive care unit during the detection and elimination of reservoirs of infection in the unit.

Strain 8 was isolated from a recurrent otitis externa associated with an underlying chronic suppurative otitis media in a man of 27 . The otitis externa had been treated with neomycin and hydrocortisone (neo-cortef) lotion locally and the otitis media with ampicillin.

\section{BACTERIOLOGICAL STUDIES}

The eight field strains were compared with the seven NCTC reference strains (table I) in a wide range of biochemical tests (table II). All tests were recorded at or up to five days except where stated in parentheses in the text below. When possible strains were incubated at their optimum growth temperature. The following tests were carried out mainly by the methods and media described by Cowan and Steel (1965); particular methods where several are given and modifications to the method or medium appear in parentheses: aesculin hydrolysis (agar), acid production from a range of ammonium salt sugars (New Zealand agar $13 \mathrm{~g}$ in place of Japanese agar $20 \mathrm{~g}$, bromothymol blue $0.03 \mathrm{~g}$ in place of $4 \mathrm{ml}$ of 


\begin{tabular}{lll}
\hline All Strains Positive in & \\
\hline Catalase production & Growth on MacConkey's agar & Nitrate reduction \\
Deoxyribonuclease production & $\begin{array}{l}\text { Growth on } \beta \text {-hydroxybutyrate } \\
\text { Gelatinase production }\end{array}$ & $\begin{array}{l}\text { Oxidase production } \\
\text { Gydrogen-sulphide production }\end{array}$ \\
$\begin{array}{l}\text { Growth at room temperature } \\
\text { Motility }\end{array}$ & Tween 20 hydrolysis \\
\hline
\end{tabular}

Table IIa

All Strains Negative in

Acid from PWS ${ }^{2}$ glucose

Acid from glucose $10 \mathrm{~g} / 100 \mathrm{~m}$

Acid from lactose $10 \mathrm{~g} / 100 \mathrm{ml}$

Acid from ASS ${ }^{3}$ adonitol

Acid from ASS dulcitol

Acid from ASS ethanol

Acid from ASS fructose

Acid from ASS glycerol
Acid from ASS inositol

Acid from ASS lactose

Acid from ASS mannitol

Acid from ASS raffinose

Acid from ASS rhamnose

Acid from ASS salicin

Acid from ASS sorbitol

Acid from ASS trehalose
Acid from ASS xylose

Arginine desimidase

Arginine dihydrolase

Fluorescence on King's B

medium

Gas from PWS glucose

Gluconate oxidation

Growth on cetrimide

Indole production
KCN tolerance

Lysine decarboxylase

Malonate utilization

Phenylalanine deamination

Poly- $\beta$-hydroxybutyrate inclusion granules Starch hydrolysis

$\beta$-Galactosidase production (ONPG)

3-Ketolactose production

Table IIb

\begin{tabular}{|c|c|c|c|}
\hline Strains Differ in & Positive & Negative & Strains Giving the Less Common Result \\
\hline Acid from ASS glucose & 8 & 7 & 4, 8 and NCTC 10695, 10736, 10738, 10762, 10763 \\
\hline Acid from ASS arabinose & 8 & 7 & 4,8 and NCTC $10735,10736,10738,10762,10763$ \\
\hline Acid from ASS cellobiose & 2 & 13 & NCTC 10735,10737 \\
\hline Acid from ASS maltose & 8 & 7 & 4,8 and NCTC $10695,10736,10738,10762,10763$ \\
\hline Acid from ASS sucrose & 7 & 8 & $1,2,3,6,7$ and NCTC 10735,10737 \\
\hline Aesculin hydrolysis & 1 & 14 & NCTC 10735 \\
\hline Alkali production on Christensen's citrate & 4 & 11 & 1,3 and NCTC 10735,10737 \\
\hline Casein digestion & 12 & 3 & NCTC $10736,10737,10763$ \\
\hline Growth on $\mathrm{NaCl} 6 \mathrm{~g} / 100 \mathrm{ml}$ & 5 & 10 & 4,8 and NCTC $10738,10762,10763$ \\
\hline Growth on $\mathrm{NaCl} 7 \mathrm{~g} / 100 \mathrm{ml}$ & 5 & 10 & 4,8 and NCTC $10738,10762,10763$ \\
\hline Growth on Salmonella-Shigella (S.S.) agar & 7 & 8 & $4,5,8$ and NCTC $10695,10738,10762,10763$ \\
\hline Growth at $5^{\circ} \mathrm{C}$ & 5 & 10 & 2,3 and NCTC $10735,10736,10737$ \\
\hline Growth at $37^{\circ} \mathrm{C}$ & 12 & 3 & NCTC $10735,10736,10737$ \\
\hline Growth at $42^{\circ} \mathrm{C}$ & 8 & 7 & $1,2,3$ and NCTC $10695,10735,10736,10737$ \\
\hline Growth on Simmons' citrate & 3 & 12 & 3 and NCTC 10735, 10737 \\
\hline Nitrite reduction & 8 & 7 & $2,3,5,6,7$ and NCTC 10738,10762 \\
\hline Opalescence on LV agar & 13 & 2 & NCTC 10736,10737 \\
\hline Ornithine decarboxylase & 13 & 2 & 1,3 \\
\hline Pigment production on tyrosine & 8 & $\overline{7}$ & $1,2,8$ and NCTC $10735,10736,10762,10763$ \\
\hline Tyrosine hydrolysis & 8 & 7 & 2,8 and NCTC $10735,10736,10737,10762,10763$ \\
\hline Urease production & 3 & 12 & 1 and NCTC 10695, 10763 \\
\hline & Alkaline & Negative & \\
\hline Hugh and Leifson O-F test & 13 & 2 & 2 and NCTC 10735 \\
\hline
\end{tabular}

Table IIc

Table IIa, b, c Biochemical characters of Pseudomonas putrefaciens

${ }^{1}$ One strain negative in nutrient gelatin stab but positive by plate method

2PWS = peptone water sugar

${ }^{3} \mathrm{ASS}=$ ammonium salt sugar

a $0.2 \mathrm{~g} / 100 \mathrm{ml}$ solution of bromocresol purple), acid and gas production from glucose peptone water sugar (Andrade's indicator, final concentration of carbohydrate $0.75 \mathrm{~g} / 100 \mathrm{ml}$ ), catalase production (method 1, one day), alkali production on Christensen's citrate (ferric ammonium citrate and $\mathrm{Na}_{2} \mathrm{~S}_{2} \mathrm{O}_{3}$ omitted, New Zealand agar $11 \mathrm{~g}$ in place of Japanese agar $20 \mathrm{~g}$ ), dihydrolase for arginine and decarboxylases for lysine and ornithine (method 1), fluorescence on medium B of King, Ward, and Raney (New Zealand agar $15 \mathrm{~g}$ in place of Japanese agar
$20 \mathrm{~g}$ ), gelatinase production (methods 1 and 3 ), gluconate oxidation (method 2 , two days), acid production from glucose $10 \mathrm{~g} / 100 \mathrm{ml}$ and lactose $10 \mathrm{~g} / 100 \mathrm{ml}$ (New Zealand agar $10 \mathrm{~g}$ in place of Japanese agar $20 \mathrm{~g}$ ), reaction in $\mathrm{O}-\mathrm{F}$ medium of Hugh and Leifson $(6 \mathrm{ml}$ of a $1 \mathrm{~g} / 100 \mathrm{ml}$ aqueous solution of bromothymol blue instead of $15 \mathrm{ml}$ of a $0.2 \mathrm{~g} / 100 \mathrm{ml}$ aqueous solution), hydrogen-sulphide production (methods 1-Oxoid, and 3), indole production (method 2, two days), KCN tolerance (two days), opalescence on lecithovitellin (LV) agar, 
growth on MacConkey's agar, malonate utilization (two days), motility (method 1 , one day), $\beta$-galactosidase production (ONPG, two days), oxidase production (one day), phenylalanine deamination (method 1, two days), starch hydrolysis (method 1), tyrosine hydrolysis (New Zealand agar $11 \mathrm{~g}$ in place of Japanese agar $20 \mathrm{~g}$, production of brown melaninlike pigment also recorded), and urease production (method 1). Tests for nitrate and nitrite reduction were carried out as described by Cowan and Steel (1965) except that the reagents used were those of Crosby (1967) in which the non-carcinogen, Cleve's acid, is used in place of $\alpha$-naphthylamine.

The following tests were carried out by the method given in the reference in parentheses which also enclose any modifications: presence of arginine desimidase (Thornley, 1960), casein digestion (prepared from Oxoid skim milk powder $50 \mathrm{~g}$, New Zealand agar $25 \mathrm{~g}$, and distilled water $1500 \mathrm{ml}$ ), growth on cetrimide agar (Brown and Lowbury, 1965), production of extracellular deoxyribonuclease (Oxoid DNase agar but with modification of Schreier, 1969), production of 3-ketolactose from lactose (Bernaerts and de Ley, 1963, two days), reduction of selenite, $0.4 \mathrm{~g} / 100 \mathrm{ml}$ (Lapage and Bascomb, 1968; $\mathrm{Na}_{2} \mathrm{HPO}_{4}$ anhydrous $9.5 \mathrm{~g}$ in place of $\mathrm{Na}_{2} \mathrm{HPO}_{4} .12 \mathrm{H}_{2} \mathrm{O} 4.3 \mathrm{~g}, \mathrm{Na}_{2} \mathrm{HPO}_{4} .2 \mathrm{H}_{2} \mathrm{O} 0.565 \mathrm{~g}$ instead of $2.8 \mathrm{~g}$, two days) and hydrolysis of tween 20 and tween 80 (Sierra, 1957). Growth with $\beta$-hydroxybutyric acid $0.5 \mathrm{~g} / 100 \mathrm{ml}$ as a sole carbon source was tested on the basal medium of Owens and Keddie (1968) and if growth was present after two days' incubation the bacteria were stained with Sudan Black B to test for the presence of poly- $\beta$ hydroxybutyrate inclusion granules.

Growth on Simmons' citrate medium (Oxoid) was confirmed by serial subculture. Growth at $5^{\circ} \mathrm{C}$, room temperature, $37^{\circ}$ and $42^{\circ} \mathrm{C}$, was recorded from ordinary nutrient broth, and pigment production on ordinary nutrient agar. Salt tolerance was tested on both 6 and $7 \mathrm{~g} / 100 \mathrm{ml}$ of $\mathrm{NaCl}$ incorporated in nutrient agar. Ability to grow on SalmonellaShigella agar was tested on Oxoid SS agar CM99.

Sensitivity to the following antimicrobial agents was also determined, by the disc method, on Oxoid Diagnostic Sensitivity Test agar to which lysed horse blood (final concentration $0.25 \%$ ) is added in our media laboratory (the concentrations are given in table III): optochin (Oxoid DD1); bacitracin (Oxoid DD2); erythromycin, chloramphenicol, tetracycline, penicillin $\mathrm{G}$, oleandomycin, novobiocin, sulphafurazole (Oxoid multodisk 11-14C); streptomycin, colistin methane sulphonate, ampicillin, nalidixic acid, nitrofurantoin (Oxoid Multodisł U1); carbenicillin, gentamicin (Mast); neomyci sulphate (Mycifradin, Upjohn Co); clindamycie hydrochloride (Dalacin, Upjohn Co); lincomyciñ hydrochloride (Lincocin, Upjohn Co), and vibrio-

\begin{tabular}{llllll}
\hline All Strains Sensitive to & \\
\hline Chloramphenicol & $(10 \mu \mathrm{g})$ & Gentamicin & $(10 \mu \mathrm{g})$ & Neomycin sulphate & $(30 \mu \mathrm{g})$ Tetracycline \\
Erythromycin & $(10 \mu \mathrm{g})$ & Nalidixic Acid & $(30 \mu \mathrm{g})$ & Nitrofurantoin & $(10 \mu \mathrm{g})$ \\
\hline
\end{tabular}

Table IIIa

All Strains Resistant to

\begin{tabular}{|c|c|c|c|}
\hline $\begin{array}{l}\text { Bacitracin }^{1} \\
\text { Lincomycin hydrochloride }(2 \mu \mathrm{g})\end{array}$ & $\begin{array}{l}\text { Novobiocin }(5 \mu \mathrm{g}) \\
\text { Optochin }\end{array}$ & $\begin{array}{l}\text { Penicillin G ( } 1.5 \text { units }) \\
\text { Sulphafurazole }(100 \mu \mathrm{g})\end{array}$ & $0 / 129^{3}$ \\
\hline
\end{tabular}

Table IIIb

\begin{tabular}{lccc}
\hline Strains Differ in & Sensitive & Resistant & Strains Giving the Less Common Result \\
\hline Ampicillin $(25 \mu \mathrm{g})$ & 5 & 10 & 2,7 and NCTC 10735, 10736, 10737 \\
Carbenicillin $(25 \mu \mathrm{g})$ & 13 & 24 & 6 and NCTC 10738 \\
Clindamycin hydrochloride $(2 \mu \mathrm{g})$ & 14 & 1 & NCTC 10738 \\
Colistin methane sulphonate $(200 \mu \mathrm{g})$ & 10 & 5 & 3,8 and NCTC 10735, 10737, 10763 \\
Oleandomycin $(5 \mu \mathrm{g})$ & 14 & 1 & 6 \\
Streptomycin $(25 \mu \mathrm{g})$ & 13 & 2 & 5,6 \\
\hline
\end{tabular}

Table IIIc

Table IIIa, b, c Sensitivity of Pseudomonas putrefaciens to antimicrobial agents

${ }^{1}$ Discs prepared from solution containing 1.8 units $/ \mathrm{ml}$

'Discs prepared from solution containing $0.45 \mathrm{mg} / \mathrm{ml}$

'Dises prepared from solution containing $1 \mathrm{mg} / \mathrm{ml}$

'These strains also resistant at $100 \mu \mathrm{g}$ 
static agent 0/129 (solution prepared using BDH 2, 4-diamino-6, 7-di-iso-propyl pteridine phosphate).

\section{Results}

The results are given in table II and arranged by tests in which all strains gave a positive or negative result and tests in which the strains differed. The strain number of those strains giving the less common result in each of the tests in which the strains gave different results is given so that the results for each individual strain can be reconstructed.

The organisms were motile Gram-negative rods with colonies on nutrient agar that produced a highly characteristic salmon-pink to reddish-brown pigment. Three of the four NCTC reference strains isolated from non-clinical material grew aerobically at $5^{\circ} \mathrm{C}$ and at room temperature but failed to do so at $37^{\circ}$ and $42^{\circ} \mathrm{C}$; two of these three were fishery isolates. Most of the remaining strains, from clinical material, failed to grow at $5^{\circ} \mathrm{C}$ but grew at room temperature, $37^{\circ}$, and $42^{\circ} \mathrm{C}$. Although the strains could be divided into two groups on their growth temperature range and these showed good correlation with their source of isolation each group contained both saccharolytic and non-saccharolytic strains tested. Saccharolytic strains typically produced acid from glucose, arabinose, maltose, and sucrose ammonium salt sugars although two strains were able to produce acid from cellobiose and NCTC 10695 ( $P$. rubescens) produced acid from arabinose only (table II).

\section{Discussion}

The eight Pseudomonas putrefaciens field strains examined in this study agree well in their characteristics with those of the seven strains deposited in the National Collection of Type Cultures (tables II and III) and with those given by Iizuka and Komagata (1964), Levin (1968, 1972), von Graevenitz and Simon (1970), Hugh (1970), Gilardi (1972, 1973), and Riley et al (1972). However, Iizuka and Komagata (1964) could not demonstrate cytochrome oxidase in their two strains but NCTC 10735, one of their strains, was found to produce oxidase in tests in this laboratory. Occasional strains of $P$. putrefaciens fail to decarboxylate ornithine (this series, table II; Levin, 1972) but von Graevenitz and Simon (1970) found all their 13 strains unable to decarboxylate ornithine by Falkow's (1958) method which is possibly unsuitable for pseudomonads since the test was devised for the separation of strains of Citrobacter, Escherichia, Salmonella, and Shigella. Further, NCTC 10762 is assumed to be one of the
13 strains described by von Graevenitz and Simon (1970) and was able to decarboxylate ornithine when tested by Møller's (1955) method. Gilardi $(1972,1973)$ found that none of his strains produced opalescence on LV agar, whilst 13 of our strains did so, and seven of 13 of his strains produced acid from fructose whilst none of our strains did so.

Strains of Pseudomonas putrefaciens are easy to identify since they have a distinct salmon pink to reddish-brown pigment, are the only commonly isolated non-fermentative organisms able to produce $\mathrm{H}_{2} \mathrm{~S}$ on triple sugar iron agar and, apart from occasional strains of Pseudomonas cepacia, usually to decarboxylate ornithine.

The sensitivity of our strains to antimicrobial agents (table III) agrees well with those given by Gilardi (1972) and von Graevenitz and Simon (1970). Two strains were resistant to streptomycin and came from different areas in Tanzania, one of which was the only strain in the present series resistant to oleandomycin and also one of the two strains resistant to carbenicillin.

Levin (1972) divided the 54 strains of Pseudomonas putrefaciens (including $P$. rubescens ATCC 19857) that he examined into two groups which he suggested had possibly evolved by mutation and divergent evolution with the temperature of the habitat acting as a selective mechanism. He distinguished the two groups (table IV) on the ability of the strains to grow in added $\mathrm{NaCl}$ at a concentration of $6 \mathrm{~g} / 100 \mathrm{ml}$ and on the guanine plus cytosine (G-C) content of their deoxyribonucleic acid (DNA). The first group comprised 37 isolates unable to grow in added $\mathrm{NaCl}$ and with a G-C content of their DNA within a range of 47.8 to $50.8 \%$. This group included all isolates from fishery sources of which none grew at $35^{\circ} \mathrm{C}$ and other isolates from diverse sources capable of growth at $35^{\circ} \mathrm{C}$. The second group, comprising 16 strains able to grow in added $\mathrm{NaCl}$ and with a G-C content of their DNA within a range of 55.9 to $59 \%$, were mostly of human clinical origin and all isolates in the group grew at $35^{\circ} \mathrm{C}$.

Riley et al (1972) were also able to divide into two groups, on the basis of salt tolerance, the 109 cultures of $P$. putrefaciens they examined (table IV). Strains of their first group were unable to grow in added $\mathrm{NaCl}$ at a concentration of $7 \mathrm{~g} / 100 \mathrm{ml}$ and in addition failed to grow on Salmonella-Shigella agar and produced acid from arabinose, dextrin, maltose, and sucrose in a modified oxidativefermentative medium. Strains of their second group in addition to growing in added $\mathrm{NaCl}$ were able to grow on Salmonella-Shigella agar and failed to produce acid from carbohydrates except for 'variable' (sic) results with glucose and fructose. Strains of the 


\begin{tabular}{|c|c|c|c|c|c|c|}
\hline \multirow[t]{2}{*}{ Character } & \multicolumn{2}{|l|}{ Levin (1972) } & \multicolumn{2}{|c|}{ Riley, Tatum, and Weaver (1972) } & \multicolumn{2}{|l|}{ Present Study } \\
\hline & Group 1 & Group 2 & Group 1 & Group 2 & Group 1 & Group 2 \\
\hline $\begin{array}{l}\text { Growth } \mathrm{NaCl} 6 \text { or } 7 \mathrm{~g} / 100 \mathrm{ml} \\
\text { G-C content } \\
\text { Growth SS agar } \\
\text { Saccharolytic activity } \\
\text { Growth at } 35 \text { or } 37^{\circ} \mathrm{C} \\
\text { Source }\end{array}$ & $\begin{array}{l}-\overline{47 \cdot 8-50 \cdot 8 \%} \\
\text { NT } \\
\text { NT } \\
\text { d } \\
\text { Mainly } \\
\text { fishery }\end{array}$ & $\begin{array}{l}+ \\
55 \cdot 9-59 \% \\
\text { NT } \\
\text { NT } \\
+ \\
\text { Mainly human } \\
\text { clinical }\end{array}$ & $\begin{array}{l}\overline{\text { NT }} \\
- \\
+ \\
+ \\
\text { Mainly human }\end{array}$ & $\begin{array}{l}+ \\
\text { NT } \\
+ \\
- \\
+ \\
\text { clinical }\end{array}$ & $\begin{array}{l}\overline{\text { NT }} \\
- \\
\overline{+} \\
\text { d } \\
\text { Fishery and } \\
\text { clinical }\end{array}$ & $\begin{array}{l}+ \\
\text { NT } \\
+ \\
- \\
+ \\
\text { Human } \\
\text { clinical }\end{array}$ \\
\hline
\end{tabular}

Table IV Separation of Pseudomonas putrefaciens isolates into two groups by various authors

$+=$ Majority of strains give a positive result

- = Majority of strains give a negative result

$\mathrm{d}=$ Some strains, generally fishery isolates, give a negative result

NT $=$ not tested

first group also gave 'variable' results with glucose and fructose. The results of our carbohydraie utilization tests agree well with those of Riley et al (1972) except that those strains in our series able to produce acid from arabinose, maltose, and sucrose also produced acid from glucose, two strains produced acid from cellobiose, and none produced acid from fructose. The majority of strains described by Riley et al (1972) grew at $35^{\circ} \mathrm{C}$ (possibly few or no fishery isolates were included in their series). These authors gave only the range of sources of all their isolates together and not for each group.

Our strains could also be divided into two groups like those of Riley et al (1972) on the basis of salt tolerance, growth on Salmonella-Shigella agar and saccharolytic activity (table IV). The first group comprised 10 strains unable to grow in added $\mathrm{NaCl}$ at a concentration of either 6 or $7 \mathrm{~g} / 100 \mathrm{ml}$ of which eight were also unable to grow on Salmonella-Shigella agar and nine were saccharolytic. Most isolates in the group, including some strains from clinical material, grew at $35^{\circ} \mathrm{C}$ but three failed to do so and two of these three were fishery isolates. The second group comprised five strains able to grow in added $\mathrm{NaCl}$ all of which also grew on Salmonella-Shigella agar and failed to produce acid from carbohydrates. All isolates in this group grew at $37^{\circ} \mathrm{C}$ and all were from human clinical sources. The 13 strains of $P$. putrefaciens described by Gilardi (1973) all tolerated $\mathrm{NaCl}$ at a concentration of $6.5 \mathrm{~g} / 100 \mathrm{ml}$ and grew on SalmonellaShigella agar and most were non-saccharolytic; the isolates were mainly of clinical origin.

The unexpected finding of Levin (1972) that all his isolates from fishery sources were unable to grow in added $\mathrm{NaCl}$ was confirmed with the strains in our series. All our three fishery isolates (from oyster, haddock, and cuttlefish (table I) failed to grow in added $\mathrm{NaCl}$ and the five strains able to grow in added $\mathrm{NaCl}$ comprised the two isolates from ear infections and three others isolated from faeces, pus, and bottled blood respectively. This may explain why Riley et al (1972) were unable to find a difference in geographical distribution of the two groups they found. These authors thought that because of the difference in salt tolerance between their two groups it would be reasonable to expect that isolates able to grow in added $\mathrm{NaCl}$ would be isolated from sources located near coastal areas.

Since two of the reference strains included in the present study were isolated from cutting oil and oib brine respectively (table I) and one of the field strains was isolated from the ear of an engineer (strain 4) it is possible that ear wax contains a substance alse present in oil which promotes the growth of $P$ : putrefaciens and this may explain why strains of this taxon appear to play a pathogenic role mainly in cases of otitis media.

We are grateful to the Department of Health and Social Security whose grant for the identification of bacteria using a computer enabled this work to be carried out. Our thanks are also due to all those who sent us strains of Pseudomonas putrefaciens for identification especially to $\mathrm{Dr}$ J. D. Abbott of Manchester Public Health Laboratory who kindly provided us with clinical details on one of the two cases of ear infection, and to Dr T. L. C. Dale of Beecham Products (UK) for information on the second case.

\section{References}

Barrow, G. I., and Miller, D. C. (1969). Marine bacteria in oysters purified for human consumption. Lancet, 2, 421-423.

Bernaerts, M. J., and Ley, J. de (1963). A biochemical test for crown gall bacteria. Nature (Lond.), 197, 406-407.

Brown, V. I., and Lowbury, E. J. L. (1965). Use of an improved cetrimide agar medium and other culture methods for Pseudomonas aeruginosa. J. c in. Path., 18, 752-756.

Castell, C. H., Richards, J. F., and Wilmot, I. (1949). Pseudomonas putrefaciens from cod fillets. J. Fish. Res. Bd Canad., 7, 430-431.

Chai, T., Chen, C., Rosen, A., and Levin, R. E. (1968). Detection and incidence of specific species of spoilage bacteria on fish. II. Relative incidence of Pseudomonas putrefaciens and fluorescent pseudomonads on haddock fillets. Appl. Microbiol., 16, 1738-1741. 
Cowan, S. T., and Steel, K. J. (1965). Manual for the Identification of Medical Bacteria. University Press, Cambridge.

Crosby, N. T. (1967). The determination of nitrite in water using Cleve's acid, 1-naphthylamine-7-sulphonic acid. Proc. Soc. Wat. Treat. Exam., 16, 51-55.

Derby, H. A., and Hammer, B. W. (1931). Bacteriology of butter. IV. Bacteriological studies on surface taint butter. Bull. Iowa St. agric. exp. Sta., 145, 385-416.

Falkow, S. (1958). Activity of lysine decarboxylase as an aid in the identification of Salmonellae and Shigellae. Amer. J. clin. Path., 29, 598-600.

Gilardi, G. L. (1972). Infrequently encountered Pseudomonas species causing infection in humans. Ann. intern. Med., 77, 211-215.

Gilardi, G. L. (1973). Nonfermentative Gram-negative bacteria encountered in clinical specimens. Antonie v. Leeuwenhoek, 39, 229-242.

von Graevenitz, A., and Simon, G. (1970). Potentially pathogenic, nonfermentative, $\mathrm{H}_{2} \mathrm{~S}$-producing Gram-negative rod (Ib). Appl. Microbiol., 19, 176.

Hugh, R. (1970). A practical approach to the identification of certain nonfermentative Gram-negative rods encountered in clinical specimens. Publ. Hlth Lab., 28, 168-187.

Iizuka, H., and Komagata, K. (1963a). An attempt at grouping of the genus Pseudomonas. J. gen. appl. Microbiol. (Tokyo), 9, 73-82.

lizuka, H., and Komagata, K. (1963b). Taxonomy of genus Pseudomonas with special reference to their modes of metabolism of carbon compounds. J. gen. appl. Microbiol. (Tokyo), 9, 83-95.

Iizuka, H., and Komagata, K. (1964). Microbiological studies on petroleum and natural gas. II. Determination of pseudomonads isolated from oil-brines and related materials. J. gen. appl. Microbiol. (Tokyo), 10, 223-231.

King, E. O. (1964). The Identification of Unusual Pathogenic GramNegative Bacteria. National Communicable Disease Center, Atlanta, Georgia.

Komagata, K., Iizuka, H., and Takahashi, M. (1965). Taxonomic evaluation of nitrate respiration and carbohydrate fermentaiion in aerobic bacteria. J. gen. appl. Microbiol. (Tokyo), 11, 191-201.
Lapage, S. P., and Bascomb, S. (1968). Use of selenite reduction in bacterial classification. J. appl. Bact., 31, 568-580.

Levin, R. E. (1968). Detection and incidence of specific species of spoilage bacteria on fish. I. Methodology. Appl. Microbiol., 16, 1734-1737.

Levin, R. E. (1972). Correlation of DNA base composition and metabolism of Pseudomonas putrefaciens isolates from food, human clinical specimens, and other sources. Antonie v. Leeuwenhoek, 38, 121-127.

Long, H. F., and Hammer, B. W. (1941). Distribution of Pseudomonas putrefaciens. J. Bact., 41, 100-101.

Minagawa, M. (1963). Studies on the strains closely related to Vibrio parahaemolyticus and reddish brown pigment-producing Pseudomonas isolated from the stools of patients of acute enteritis. A. R. Inst. Food Microbiol. (Chiba Univ.), 16, 9-23.

Møller, V. (1955). Simplified tests for some amino acid decarboxylases and for the arginine dihydrolase system. Acta. path. microbiol. scand., 36, 158-172.

Owens, J. D., and Keddie, R. M. (1968). A note on the vitamin requirements of some coryneform bacteria from soil and herbage. J. appl. Bact., 31, 344-348.

Pivnick, H. (1954). Pseudomonas rubescens, a new species isolated from soluble oil emulsions. Bact. Proc., 42-43.

Pivnick, H. (1955). Pseudomonas rubescens, a new species from soluble oil emulsions. J. Bact., 70, 1-6.

Riley, P. S., Tatum, H. W., and Weaver, R. E. (1972). Pseudomonas putrefaciens isolates from clinical specimens. Appl. Microbiol. 24, 798-800.

Schreier, J. B. (1969). Modification of deoxyribonuclease test medium for rapid identification of Serratia marcescens. Amer. J. clin. Path. 51, 711-716.

Sierra, G. (1957). A simple method for the detection of lipolytic activity of micro-organisms and some observations on the influence of the contact between cells and fatty substrates. Antonie v. Leeuwenhoek, 23, 15-22.

Thornley, M. J. (1960). The differentiation of Pseudomonas from other Gram-negative bacteria on the basis of arginine metabolism. J. appl. Bact., 23, 37-52. 